\title{
TEACHING AND LEARNING MATHEMATICS THROUGH WEB-BASED RESOURCE: AN INTERACTIVE APPROACH
}

\author{
Hendra Kartika \\ Universitas Singaperbangsa Karawang \\ Jl. HS. Ronggowaluyo Telukjambe Timur, Karawang, Jawa Barat \\ E-mail: hendra.kartika@staff.unsika.ac.id
}

Submitted: 25-01-2018, Revised: 06-02-2018, Accepted: 20-05-2018

\begin{abstract}
:
The aim of this study is to investigate the effectiveness of teaching and learning process using web-based resource as an interactive approach in learning mathematics. Research method used in this study is content analysis. The web-based resource in this study is interactive mathematics website. Based on this resource, teaching and learning mathematics is divided into three steps, first, teaching and learning to give student's understanding on mathematics concepts and notation; second, teaching and learning interactive applet; and Student's independent practices. After teaching and learning, sixty-nine students were given a feedback about teaching and learning mathematics through web-based resource enrolled in linear algebra course. The 12 questionnaires by (Hsu, 2017) ware used as the instrument to collect data on participant's usage of web-based resource. Data analysis was conducted descriptively. The results of this study showed that there are positive feedback on students' satisfaction and learning interest when using a web-based resource. Also, the results showed web-based resource could help students' learning mathematics independently. Students can repeat and relearn the material that has been delivered anywhere and anytime.
\end{abstract}

Keywords: Web-Based Resources, Teaching and Learning Mathematics, Interactive Approach, Interactive Website

\section{PEMBELAJARAN MATEMATIKA BERBASIS WEB: SUATU PENDEKATAN INTERAKTIF}

\begin{abstract}
Abstrak:
Tujuan dari penelitian ini adalah untuk mengetahui efektifitas proses pembelajaran menggunakan bahan berbasis web sebagai pendekatan interaktif dalam belajar matematika. Metode penelitian yang digunakan adalah analisis konten. Sumber berbasis web dalam penelitian ini adalah website matematika interaktif. Berdasarkan sumber pembelajaran ini, pembelajaran matematika dibagi kedalam tiga langkah, yaitu pertama, pembelajaran untuk memberikan pemahaman siswa terhadap konsep dan notasi matematika; kedua, pembelajaran interaktif dengan applet; dan ketiga, latihan mandiri siswa. Setelah pembelajaran, 69 siswa yang mengikuti perkuliahan aljabar linear memberikan respon tentang pembelajaran matematika melalui sumber berbasis web. Instrumen yang digunakan adalah 12 kuesioner yang dikembangkan (Hsu, 2017). Hasil memperlihatkan bahwa terdapat respons positif dalam kepuasan dan minat belajar siswa ketika menggunakan sumber berbasis web. Hasil juga
\end{abstract}


memperlihatkan bahwa sumber berbasis web dapat membantu siswa belajar matematika secara mandiri. Siswa dapat mengulang dan mempelajari kembali materi yang telah disampaikan kapan saja dan dimana saja.

Kata Kunci: Sumber Berbasis Web, Pembelajaran Matematika, Pendekatan Interaktif, Website Interaktif

How to Cite: Kartika, H. (2018). Teaching and Learning Mathematics Through WebBased Resource: An Interactive Approach. MaPan : Jurnal Matematika dan Pembelajaran, 6 (1), 1-10.

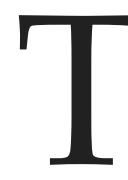

The 21st century witnessed a shift in educational paradigm, which comes from widespread use Information and Communication Technology (ICT) that has provided access to rich and innovative teaching and learning resources (Zawacki-Richter, O., Bozkurt, Alturki, \& \& Aldraiweesh, 2018; Hsu, 2017) The development of Information and Communication Technologies (ICT) enables many benefits and advances regarding all components of the educational process and play increasingly a fundamental role to support teaching and learning (Cardoso, 2016). Information technology such as computer and internet has dramatically increased the ways of teaching and learning (Su, B., Bonk, Magjuka, \& Liu, X., \& Lee, 2005). Internet and www (World Wide Web) have overshadowed every aspect of our life but education and research are of prime importance (Ahmad \& Muneebulla, 2017). Information technologies and www, has been widely used not only as a source of information, but also as a learning resource.

In the study of teaching and learning, the use of website as a learning resource is known as web-based resources. Web-based Resources is internet sites that provide these types of materials for students: dictionaries, tutorials, animations, games, practice quizzes, and labeling exercises (Mugan, 2008). In this paper, the author use web-based resource as terminology in learning mathematics based website. The terminology is used because there are two types of learning resources used by students in this research, namely tutorial and animation using java applet.

According to (Simon, 2015), by leveraging the instructional potential of web-based resource, you can increase student's engagement, expose them to authentic content, and engage them in collaborative activities that trigger critical thinking and creativity. Web-based resources have the potential to 
support a learning environment in which students explore knowledge and enhance their learning (Combes, B., \& Valli, 2007). In addition, the web makes possible interactive resources encouraging student involvement (Sheard, J., Stema, \& Markham, 2000). Therefore, with the use of these web-based resources, students can explore their curiosity independently and improve students' mathematics learning, achievement and learning motivation.

The web has a wealth of educational information across different topics, which can potentially be used to improve teaching (Chakraborty, Kanthamani, \& Chen, J., \& Subramanian, 2012). They can provide teachers and learners with a wide range of new and exciting experiences that are not possible in a traditional classroom (Hadjerrouit, 2010). However, it is relatively slow in the field of mathematics and there is a scarcity of literature in this area (Loong, 2001). Furthermore, the quality of the web contents has also been a major concern for educators, expressed by (Hartig \& \& Zhao, 2009) as scientific applications that are built upon the Web will be of "little value if scientists are skeptical of the quality of data". Thus, the use of the web in learning needs further discussion.

\section{METHOD}

The research method used in this study is content analysis. The researcher regard content analysis as a flexible method for determining content of the website. According to (Lai \& To, 2014) content analysis method has been employed in studies of human-computer interaction such as web based applications, norms of behaviour and cultural values. Thus, teaching and learning through web-based resource in this study are based on content of the website. In this approach, teaching mathematics is analysed into three steps, they are (1) Teaching for student's understanding on mathematics concepts and notation; (2) Learning interactive applet; and (3) Student's independent practices. After learning, students were given a feedback about teaching and learning mathematics through web-based resource.

The website which is used as the resource in this study is http://www.intmath.com. The reason why this website was chosen is because it is easily accessible and free. While the selected chapter is the introduction of vector. This chapter is divided into four subcontents, they are simple vectors, 2-dimensional vectors, 3-dimensional vectors and vector calculus. In subcontent on 3-dimensional vectors there is $3 \mathrm{D}$ applet that can be used interactively both by students and teachers. 


\section{Hendra Kartika}

Once the website content is analyzed, the website is piloted in classroom. The 12 questionnaires were administered on the students $(n=137)$ enrolled in linear algebra course. The sampling 69 students were selected by fifty percent technique (Lakonpol, Ruangsuwan, \& Terdtoon, 2015). This technique was used because all the students have the equal involvement in learning activities. The questionnaires looked at student's responses to the use of web-based resources for learning mathematics.

\section{RESULT AND DISCUSSION}

In this study, there are three main section for teaching and learning through web-based resource, namely introduction, teaching and learning interactively, and reflection. The following paragraph is an explanation based on the steps.

The first step learning activities is apperception. Apperception is students' readiness and awareness for study vectors. Apperception is early learning activities that include purpose about the study. In this step, students are given an initial knowledge about the importance of learning vector, such as why we study vectors and examples of everyday activities that involve vectors as describe the figure 1 .

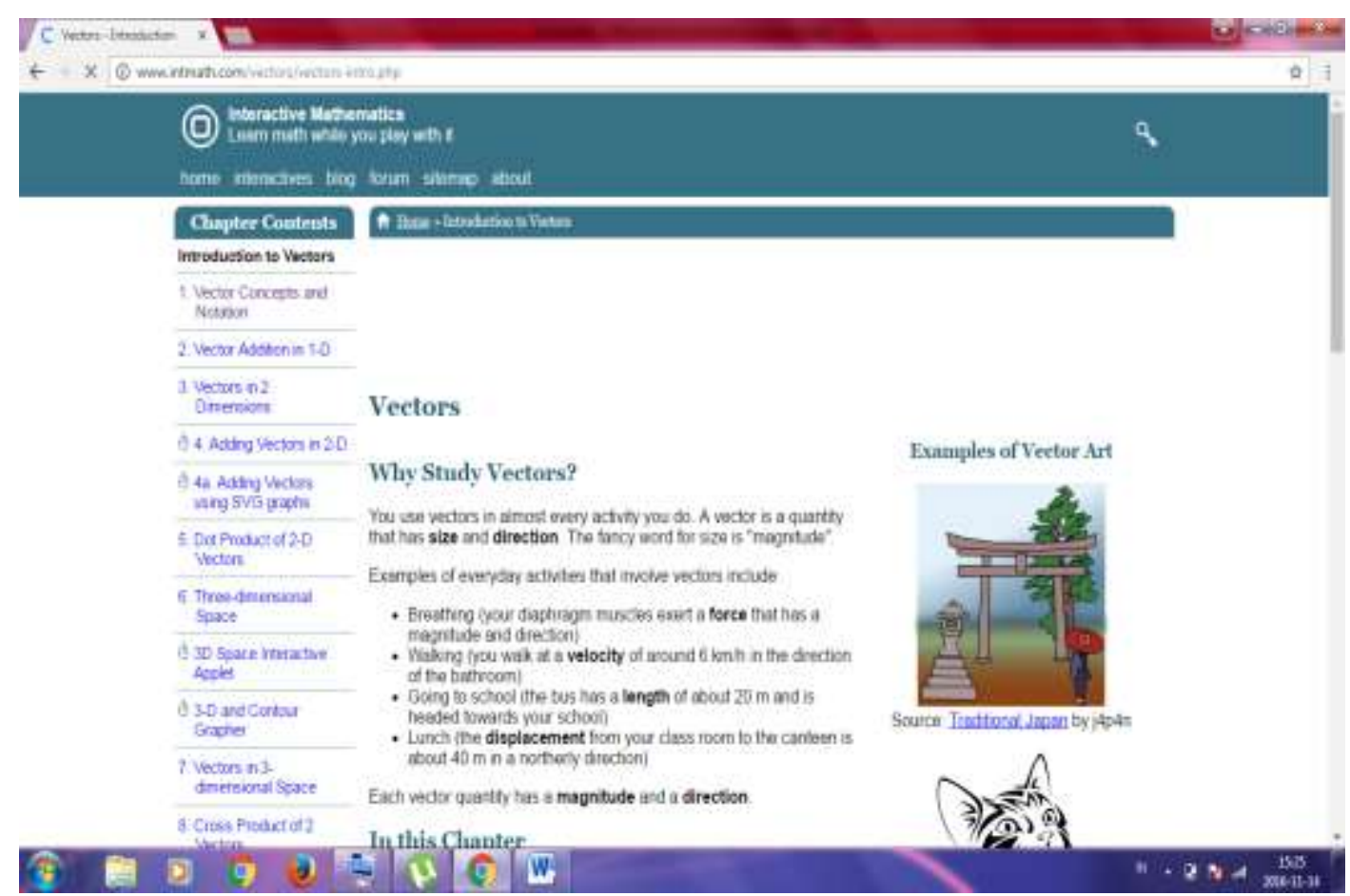

Figure 1. Introduction to Vectors 
The second steps are exploration, elaboration, and confirmation. In explanation step, students can explore their understanding about the concept of vector using 3D space interactive applet. This applet shows vectors geometrically in 3-dimensional coordinates. Furthermore, students can change the position of point $(x, y, z)$ to find others vector drawing as describe the figure 2 .

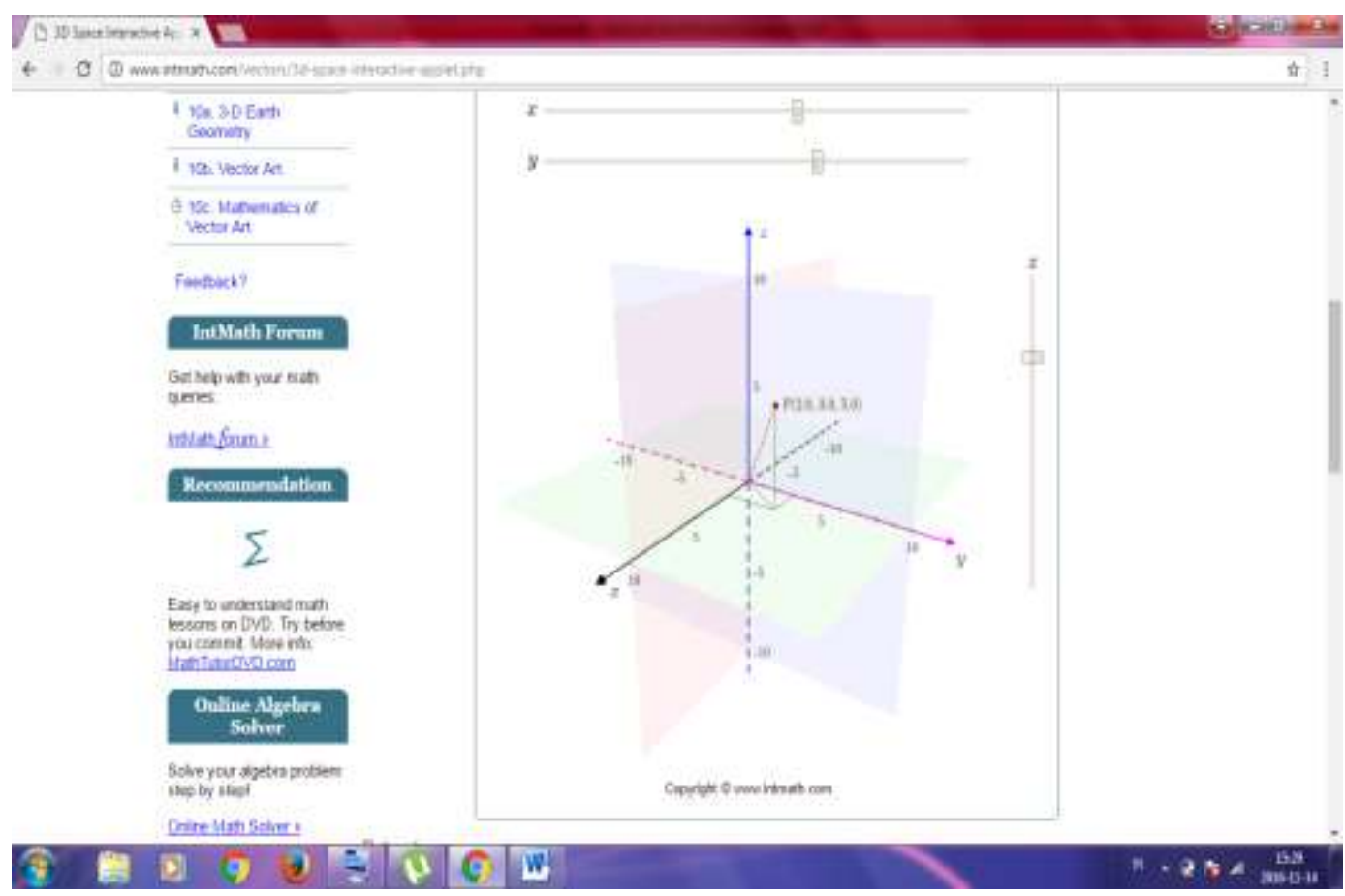

Figure 2. 3D Space Interactive Applet

On the above figure 2, the teacher provides guidance and directs students to write down their observations independently or in groups. This activity called elaboration. After that, students should present their explore and observations in front of the class. This activity called confirmation. In addition, students were given some example and exercise. as describe the figure 3 . 


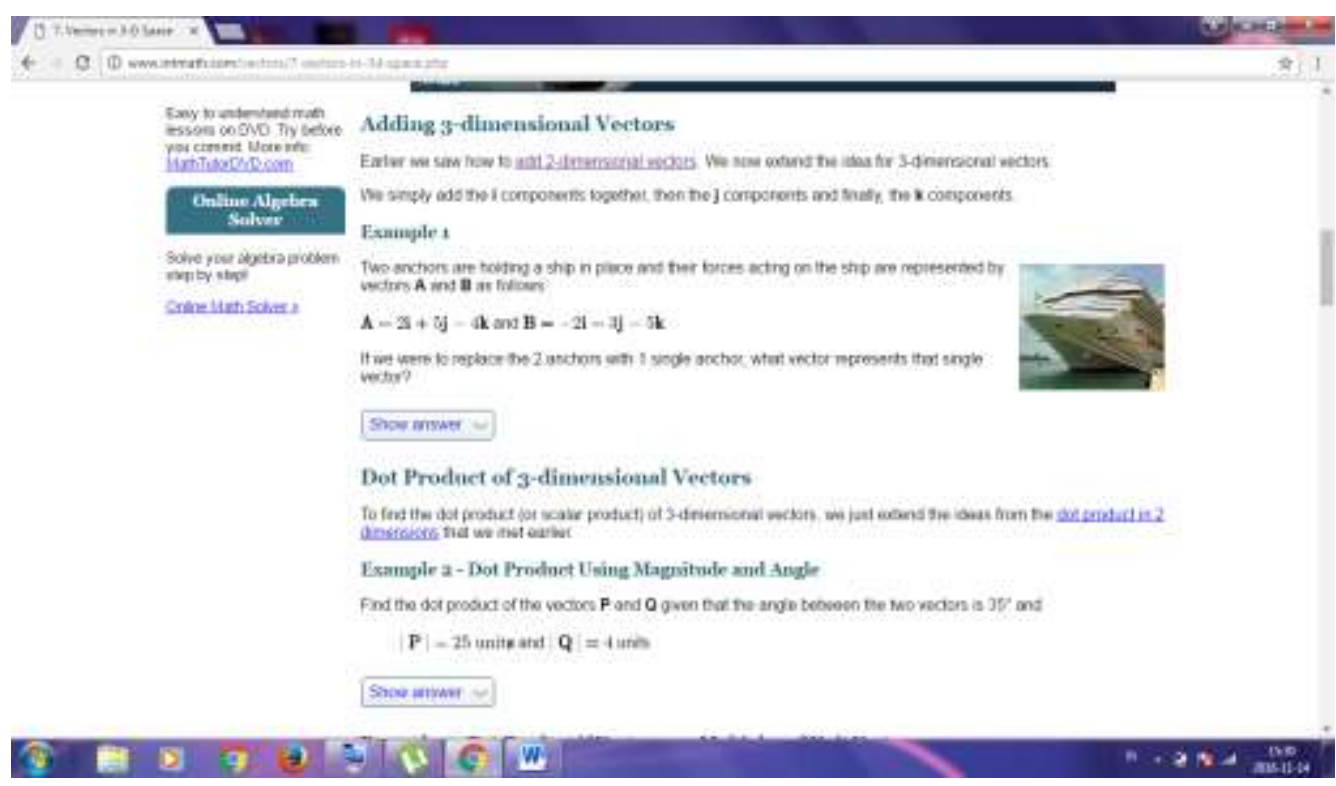

Figure 3. 3D Vectors and Some Example

The last step is reflection. Based on the teacher's guidence, students make a conclusion about the subject that they learn. In this step, teachers can give oral question for students to find out the extend to which students have understood the lesson. After that, students were given a feedback about teaching and learning vectors through web-based resource. as describe the figure 4 .

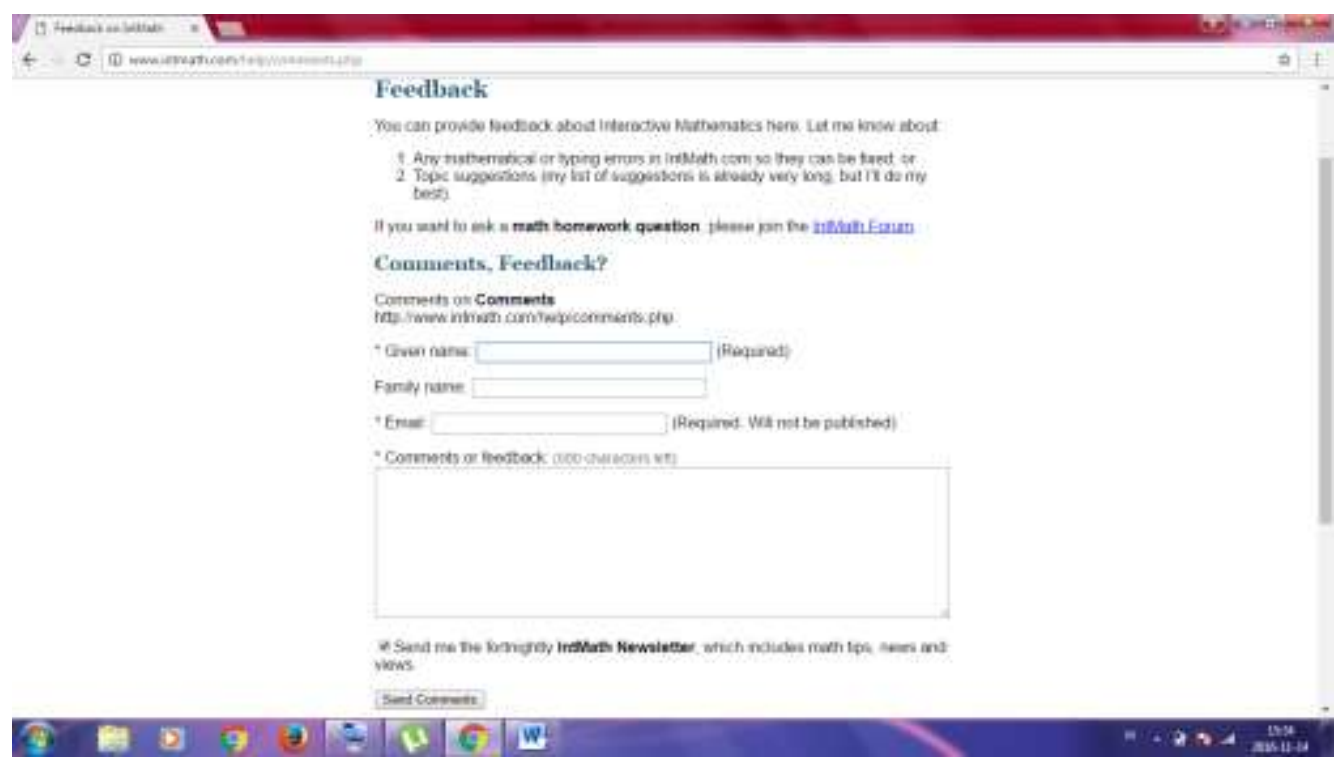

Figure 4. Fedback after Learning

6| Volume 6, No 1, June 2018 
Once the content of the website has been analyzed, the website is used in a limited way in lecture of linear algebra. Data of student's satisfaction and interest in learning were obtained through questionnaire. The result of the questionnaire is presented in table 1.

Table 1. Descriptive Data of the Items in the Questionnaire

\begin{tabular}{|c|c|c|c|}
\hline Item Descriptions & Mean & SD & $\begin{array}{c}\text { Frequency } \\
\text { (Agree- } \\
\text { Strongly } \\
\text { Agree) }\end{array}$ \\
\hline $\begin{array}{l}\text { 1. Teacher's feedbacks delivery is faster due } \\
\text { to the use of the Internet. }\end{array}$ & 3.65 & 0.48 & $65.2 \%$ \\
\hline $\begin{array}{l}\text { 2. It makes me put more heart and effort } \\
\text { into the course by using Internet. }\end{array}$ & 3.80 & 0.42 & $79.7 \%$ \\
\hline $\begin{array}{l}\text { 3. Via web-based resource, it makes me } \\
\text { more satisfied with the course. }\end{array}$ & 3.86 & 0.36 & $85.5 \%$ \\
\hline $\begin{array}{l}\text { 4. It enhances my interest in learning by } \\
\text { using Internet. }\end{array}$ & 3.60 & 0.63 & $52.2 \%$ \\
\hline $\begin{array}{l}\text { 5. It is convenient to use web-based } \\
\text { resources. }\end{array}$ & 3.67 & 0.51 & $65.2 \%$ \\
\hline $\begin{array}{l}\text { 6. I like to use computer, the Internet, and } \\
\text { multimedia to learn Mathematics. }\end{array}$ & 3.52 & 0.56 & $55.1 \%$ \\
\hline $\begin{array}{l}\text { 7. I like the traditional way to learn } \\
\text { Mathematics. }\end{array}$ & 1.96 & 1.09 & $14.5 \%$ \\
\hline $\begin{array}{l}\text { 8. I don't like to learn Mathematics through } \\
\text { computer or multimedia. }\end{array}$ & 2.09 & 1.07 & $17.4 \%$ \\
\hline $\begin{array}{l}\text { 9. I hope more teachers will teach } \\
\text { Mathematics using web-based resources. }\end{array}$ & 3.69 & 0.70 & $49.3 \%$ \\
\hline $\begin{array}{l}\text { 10. I personally prefer traditional classroom } \\
\text { to the web-based resources. }\end{array}$ & 2.77 & 0.86 & $13.0 \%$ \\
\hline $\begin{array}{l}\text { 11. I like the sense of diversity and richness of } \\
\text { the web-based resources. }\end{array}$ & 3.88 & 0.40 & $85.5 \%$ \\
\hline $\begin{array}{l}\text { 12. Overall, I am satisfied with the web-based } \\
\text { resources. }\end{array}$ & 3.99 & 0.50 & $87.0 \%$ \\
\hline
\end{tabular}

The table 1 presents data about proportion of frequency ranging from agree to strongly agree for each items on students' satisfaction and learning interest through learning using web-based resources. Overall, most students gave positive respons in all items. In the categories of students' satisfaction (items 1, 3, 5, 9, and 12), more than $45 \%$ students gave positive feedback in 
teaching and learning through web-based resources. Furthermore, in the categories of students' learning interest (items 2, 4, 6, 7, 8, 9, and 10), 82\% students also gave positive feedback. While only less than $18 \%$ students give negative feedback for the three out of seven items on learning interest $(7,8$, and 10). It proves that students are satisfied and interested with teaching and learning using web-based resources. This finding is similar to the results obtained by (Kay, Knaack, \& Petrarca, 2009) who found that the students' performances increased significantly (almost by 40\%) when they use web resources.

\section{CONCLUSION}

Based on the findings of the study, it can be concluded that the webbased resource approach has a better chance of improving students' mathematics learning, achievement, learning motivation and interest than the traditional approach. student learning independence is increasing by accessing learning resources wherever and whenever through internet connection. Moreover, the study has brought to the fore that students have positive attitude towards the web-based resource in learning mathematics. In this study, the suggested teaching concept using web-based resource can be thought as an interactive teaching and learning mathematics approach. In addition, web-based resource could help students' learning mathematics independently. Students can repeat and relearn the material that has been delivered anywhere and anytime with a web-based resources.

\section{REFERENCES}

Ahmad, S., Muneebulla, K. K., Ahmad, T. C., Approach, K. K., \& Students, B. E. (2017). Approach of B. Ed. Students towards use of ICT and web resources: A survey of teacher training colleges of Bandipora District-J \& K (India), 7 (1), 59-84.

Cardoso, A. et al. (2016). Internet-based resources to support teaching of modelling, simulation and control of physiological systems in biomedical engineering courses. IFAC-Papers Online, 46. https://doi.org/10.1016/j.ifacol.2016.07.199.

Chakraborty, S., Kanthamani, M., \& Chen, J., \& Subramanian, L. (2012). Symposium on computing for development. Retrieved October 8, 2017, from http:/ /cs.nyu.edu/ sunandan/eduweb.pdf. 
Combes, B., \& Valli, R. (2007). Learning objects: Applications, implications, \& future directions. (K. H. \& A. Koohang, Ed.). Santa Rosa: CA: Informing Science Press.

Hadjerrouit, S. (2010). Developing web-based learning resources in school education: A user-centered approach. E-Learning and Learning Objects, 6.

Hartig, O., \& Zhao, J. (2009). Using web data provenance for quality assessment. Proceedings of the 1st Int. Workshop on the Role of Semantic Web in Provenance Management (SWPM) at the International Semantic Web Conference (ISWC).

Hsu, L. (2017). Enhancing college students' satisfaction and learning interest when the teacher uses a web-based platform while teaching. American Journal of Educational Research, 5 (1), 18-24.

Kay, R., Knaack, L., \& Petrarca, D. (2009). Exploring teachers perceptions of web-based learning tools. Interdisciplinary Journal of E-Learning and Learning Objects, 5, 1-4.

Lai, L. S. L., \& To, W. (2014). Content analysis of social media: A grounded theory approach. Electronic Commerce Research, 16 (2), 138-152.

Lakonpol, T., Ruangsuwan, C., \& Terdtoon, P. (2015). Development of webbased learning environment model to enhance cognitive skills for undergraduate students in the field of electrical engineering. Educational Research and Reviews, 10 (21), 2806-2813. https:// doi.org/10.5897/ERR2015.2470.

Loong, E. Y. K. (2001). Web mathematics anyone? International Education Journal, 2 (4), 216-222.

Mugan, P. (2008). Effect of intensively using web-based resources on the performance and attitude of High School Biology Students. https:/ / doi.org/10.1.1.592.826\&rep=rep1\&type=pdf.

Sheard, J., P., Stema, M., \& \& Markham, S. (2000). What do students value?

Simon, E. (2015). Teaching with web-based resources. Retrieved October 8, 2017, from https://www.edutopia.org/blog/teaching-with-web-basedresources-edwige-simon. 
Su, B., Bonk, C. J., Magjuka, R. J., \& Liu, X., \& Lee, S. (2005). The importance of interaction in web-based education: a program-level case study of online mba courses. Journal of Interactive Online Learning, 4 (1), 1-19.

Zawacki-Richter, O., Bozkurt, A., Alturki, U., \& Aldraiweesh, A. (2018). What research says about MOOCs - An explorative content analysis. International Review Of Research In Open And Distributed Learning, 19 (1). https://doi.org/http://dx.doi.org/10.19173/irrodl.v19i1.3356. 